\author{
Lilia SUCHOCKA ${ }^{1}$ \\ Eleonora KRAJEWSKA ${ }^{2}$ \\ Małgorzata PASEK ${ }^{3}$
}

\title{
THE NEED FOR SOCIAL SUPPORT AND THE FUNCTIONING OF INDIVIDUALS IN A HEALTH-LIMITING CONDITION
}

\begin{abstract}
Introduction: Negative and difficult life experiences, and stressful situations that an individual may face, affects not only those who experience such situations but also their family and friends. In a distressing situation, such as an illness in the family, a person suffering from an illness and their closest support networks may need various types and forms of support. Difficulties in coping with demanding situations frequently result in fear, anxiety, and depression. Sufferers may feel threatened and often expect help and support from those who are close to them and from specific institutions. The issue of social support still attracts considerable interest, and is examined in this research from the perspective of various scientific disciplines.

Aim: The main aim of this study is to assess, in psychological terms, the need for social support among individuals who are in a difficult life situation because they suffer from a chronic disease.

Materials and methods: The study was conducted among chronic illness sufferers and involved 40 individuals (23 men and 17 women) hemodialyzed at St. Luke's Hospital in Tarnów. The methods used were an individual questionnaire and a survey questionnaire developed by the authors and the Berlin Social Support Scales (BSSS) developed by Ralf Schwarzer \& Ute Schulz

Results: Research findings show that emotional support is the most important type of support for a large percentage of respondents in a difficult life situation. They also need instrumental support, which involves obtaining specific information about how to cope with their condition. In an illness situation, the respondents experience fatigue, exhaustion and general anxiety. A chronic disease and the treatment associated with it can place limitations on some aspects of life and the social functioning of people affected by it. These people find it hard to enjoy the cultural and social life or to participate in recreation.
\end{abstract}

\footnotetext{
${ }^{1}$ Lilia Suchocka, PhD, Faculty of Education and Psychology, Jan Kochanowski University of Kielce, ul. Krakowska 11, 25-029 Kielce; e-mail: liliasuchocka@ibnps.eu. ORCID: 0000-0003$-0474-3955$.

2 Eleonora Krajewska, St. Luke's Provincial Hospital in Tarnów, Lwowska 178A, 33-100 Tarnów; e-mail: elakrajewska71@gmail.com. ORCID: 0000-0002-5005-7094.

${ }^{3}$ Małgorzata Pasek, PhD, University of Applied Sciences in Tarnow, ul. Mickiewicza 8, 33-100 Tarnów; e-mail: malgorzata_pasek@wp.pl (corresponding author). ORCID: 0000-0002-5638-5582 .
} 
Conclusions: Individuals in a difficult situation, such as those facing a chronic illness, expect emotional and instrumental support. A chronic illness and its treatment limits the social activity of those who are affected by it.

Keywords: social support, difficult situation, coping.

\section{INTRODUCTION}

Support is commonly defined as the assistance available to an individual in a difficult situation and as specific acts of help directed towards those who face difficult life situations or experiences. The following types of support are distinguished in the literature: a) emotional, b) informational, c) instrumental, and d) material. Emotional support involves offering emotional empathy to people in difficult situations, showing them care and building a sense of security. Informational support is usually based on providing necessary information, which helps them to get a proper understanding of their difficult situation. It is primarily focused on supplying necessary information, providing advice and information about where to seek the specialist help. Instrumental support is treated as some kind of instruction that often includes guidelines on how to cope with and solve a difficult situation. Material support most often refers to specific financial or in-kind aid (Filipiak, 2010).

Negative life experiences and difficult situations that an individual goes through frequently affect not only the person who faces such conditions, but also those who are close to them. Family members or friends usually share the strong emotions, worries and fears. In a distressing situation, such as an illness in the family, a person suffering from an illness as well as those around, usually need various types and forms of support.

Individuals who find themselves in a difficult situation often feel helpless; this is why, emotional support that allows them to work off their strong emotions (e.g. fear, sadness, regret, anger, or rage) is the most appropriate form of support. Another important type of support in such situations is informational support. It allows people in need and their family to receive information from professionals about where to search for help. This kind of support is often educational in nature. If the support is given to a chronically ill person, it should be adjusted to the individual situation and the needs of this person, and it should be multidimensional. Therefore, it is important that the support in such situations should come from a variety of people: medical personnel (doctors, nurses, and psychologists), priests and social workers, and above all, from the family members and friends (Sęk, Cieślak, 2004; Ziarko, 2014).

Any chronic disease is connected with an undesirable change in a person's life. People affected with a chronic condition often feel a heavy burden, and their illness presents many new challenges that they have to cope with. A chronic illness is a critical event in the patient's life, especially for those suffering from chronic kidney failure, when it is necessary to decide on renal replacement therapy (Bauman, 2017; Lichodziejewska-Niemierko, 2016). People who are chronically ill may become passive and withdrawn, they feel frustrated, despondent or apathetic. Consequently, they may have problems in their social relations and with following medical recommendations (Bauman, 2017; Marcinkowska, Zabiegaj, Kulik, 2016). However, if they learn to cope with this difficult situation and to live with their illness, they can still live normal and full lives despite the health limitations. That is why, treatment often becomes an important element of everyday functioning. 
Chronic renal failure is defined as a condition developing as a result of the progressing and irreversible impairment of kidneys' functions. It is an unpleasant and burdensome disease, and often has some negative consequences. A chronic illness frequently changes the mental functioning of a person, influencing their cognitive and emotional processes. Chronic illness sufferers may experience, among others, social consequences of their illness, which are manifested by changes in the social roles that they perform. In those critical life situations, they may run a risk of stigmatization, which often leads to mental and social alienation or isolation (Wiśniewska, Paczkowska, Białobrzeska, 2010).

\section{THE PURPOSE}

The main aim of the study was to assess, in psychological terms, the need for social support among individuals suffering from a chronic illness. Moreover, the study aimed at examining the specific nature of emotional states that accompany the experience of a difficult situation, and at determining to what extent a chronic illness and its treatment limit the everyday functioning.

The following research hypotheses were formulated:

$\mathrm{H}$ 1. Emotional support is the most expected support during a chronic illness, in the study group.

H 2. The perceived available instrumental and emotional support is rated the highest by the respondents facing a difficult situation connected with their illness.

$\mathrm{H}$ 3. In a difficult situation related to haemodialysis treatment, the respondents experience fatigue, exhaustion and anxiety.

$\mathrm{H}$ 4. A chronic illness places some limitations on how the respondents can function in different areas of their lives.

\section{MATERIALS AND METHODS}

The following research tools were used to conduct the research:

1. an individual questionnaire and a survey questionnaire developed by the authors,

2. the Berlin Social Support Scales (BSSS) developed by Ralf Schwarzer \& Ute Schulz. (Berlińska Skala Wsparcia Społecznego - Polish version adapted by A. Łuszczyńska, M. Kowalska, 2002)

The study was conducted among individuals suffering from a chronic illness and involved 40 respondents (including 23 men and 17 women) haemodialysed at the Dialysis Unit at St. Luke's Hospital in Tarnów. The age distribution is as follows: 8 respondents aged 41-50 (which constitutes $20 \%$ of all respondents), 22 - aged 51-60 (55\%), and 9 individuals aged $71-80(25 \%)$.

The level of respondents' education varied, with most respondents that have completed vocational education $(\mathrm{N}=15$, i.e. $37.5 \%)$ and higher education $(\mathrm{N}=13,32.5 \%)$, followed by those with secondary education $(\mathrm{N}=10$, i.e. $25.0 \%)$ and elementary education $(\mathrm{N}=2$, i.e. $5 \%$ )

Fig. 1 shows how long the respondents have been haemodialysed.

The majority ( $\mathrm{N}=21$, i.e. $52.5 \%$ ) of patients suffering from chronic kidney disease have been haemodialysed for $2-5$ years. The second largest group $(\mathrm{N}=13$, i.e. $32.5 \%)$ included those who have been haemodialysed for up to one year from the moment they were diagnosed with kidney disease. Only 2 respondents (i.e. 5\%) have been haemodialysed for 6-10 years, and 4 (10\%) for over 10 years. 


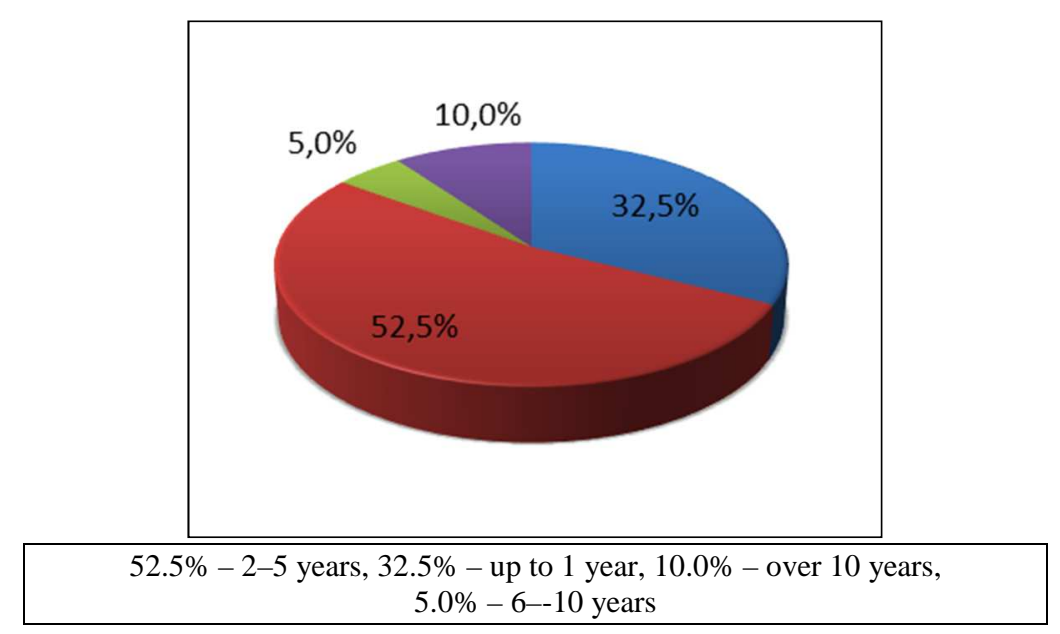

Fig. 1. Length of haemodialysis treatment

Source: Compiled by authors.

The haemodialysis treatment and disease length affect the everyday functioning, and increase the need for various types of support.

\section{RESULTS}

Difficult life situations, especially a chronic illness, often change the individual's mental functioning, influencing their cognitive processes and emotions they experience. People who suffer from a chronic illness may also experience the individual and social consequences of their condition, such as difficulties in performing their social roles or changes in these roles, limitations in their professional life. Moreover, an illness condition often results in withdrawal, limitations in functioning, or even social isolation or being rejected.

For the purpose of this study, the following were analysed: a) social support perceived by the respondents, b) emotions accompanying the respondents during their illness, and c) limitations of social activity and everyday functioning. All these three variables determine how an individual functions in a difficult situation and how they cope with a chronic disease, as well as how much support they need and how much support they are willing to receive both from the family and specialists.

Fig. 2 below shows how the respondents perceive support.

The majority in the study group $(\mathrm{N}=30$, i.e. $75.0 \%)$ could always count on receiving help from the family. The research has shown that a small number of respondents $(\mathrm{N}=8$, i.e. $20 \%$ ) received the help necessary in their illness condition, from time to time. Only one respondent $(\mathrm{N}=1$, i.e. $2.5 \%)$ stated that the family members were not interested in the problems experienced as a result of illness, and one respondent $(\mathrm{N}=1$, i.e. $2.5 \%)$ felt completely abandoned in their situation. 


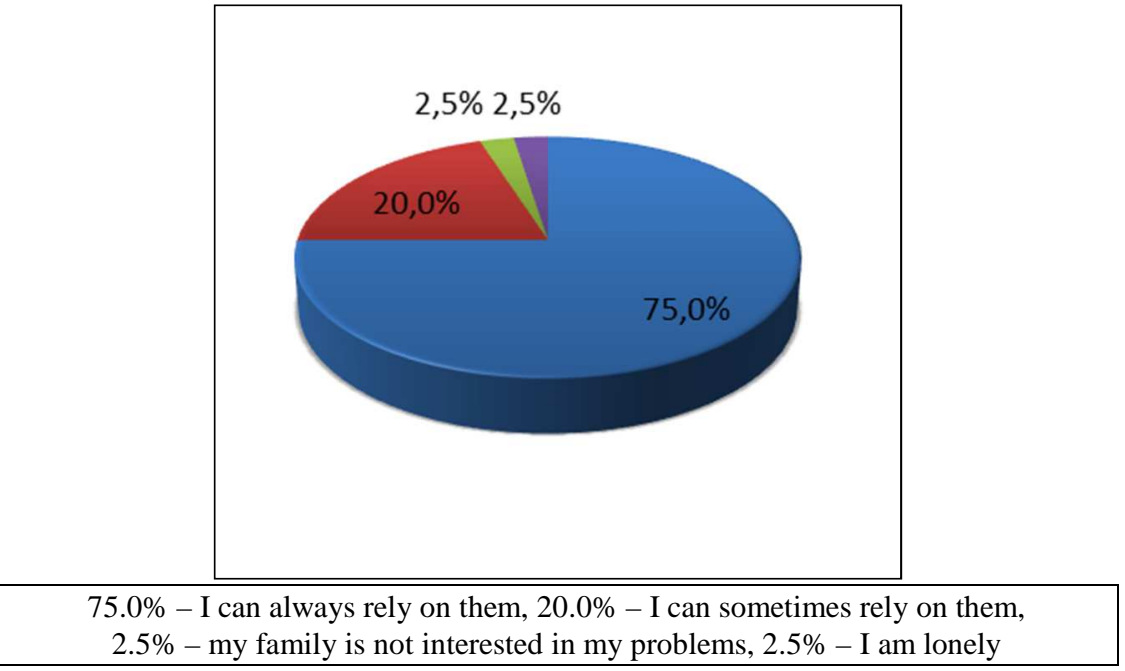

Fig. 2. Support from the close ones as perceived by respondents Source: Compiled by authors

Fig. 3 presents the results regarding the type of support that respondents expect most.

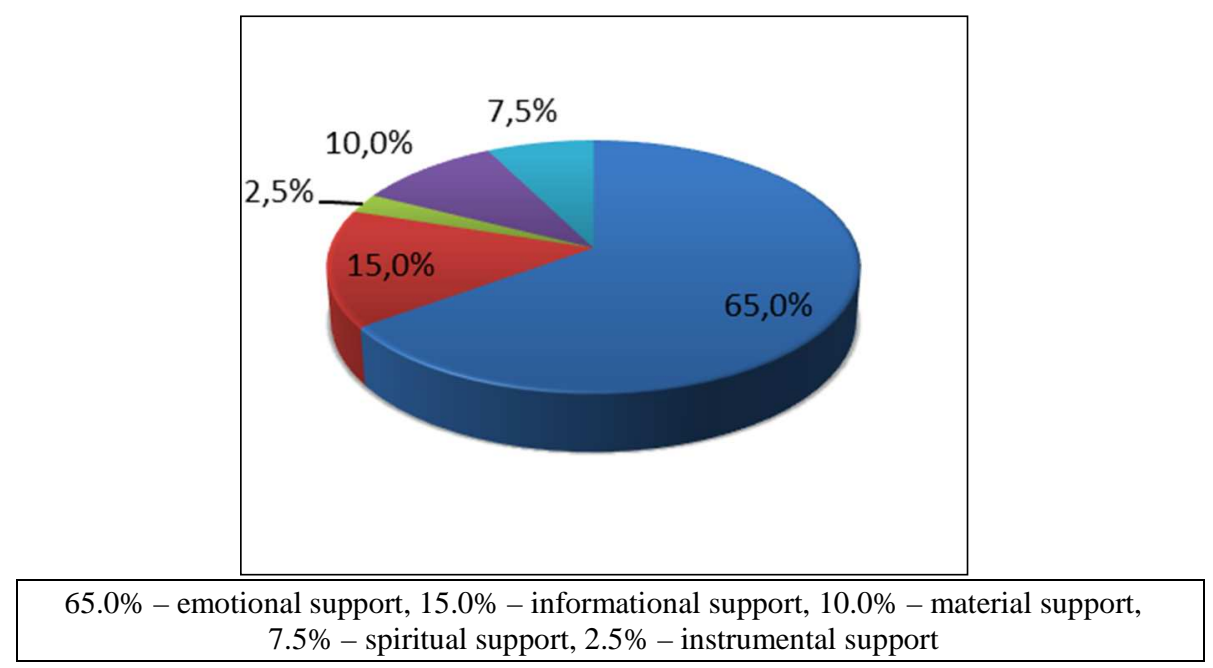

Fig. 3. Type of support most expected

Source: Compiled by authors.

Based on the obtained results, it can be concluded that the respondents were most likely to expect and need emotional support in the difficult situation they experienced $(\mathrm{N}=26$, i.e. $65.0 \%)$. This was followed by informational support $(\mathrm{N}=6$, i.e. $15 \%)$. Four respondents 
$(\mathrm{N}=4$, i.e. $10 \%)$ expected material support. Three respondents $(\mathrm{N}=3$, i.e. $7.5 \%)$ expected spiritual support and one person $(\mathrm{N}=1$, i.e. $2.5 \%)$ - instrumental support.

Table 1 below compiles mean values regarding support perception and support seeking among the respondents.

Table 1. Perceived support and support seeking based on the Berlin Social Support Scales (BSSS)

\begin{tabular}{|c|c|c|c|c|}
\hline & $\begin{array}{c}\text { Perceived } \\
\text { available } \\
\text { emotional support }\end{array}$ & $\begin{array}{c}\text { Perceived available } \\
\text { instrumental } \\
\text { support }\end{array}$ & Need for support & $\begin{array}{c}\text { Support } \\
\text { seeking }\end{array}$ \\
\hline $\begin{array}{c}\text { Mean } \\
\text { Value }\end{array}$ & $\mathbf{3 . 3 7}$ & $\mathbf{3 . 4 6}$ & $\mathbf{2 . 9 8}$ & $\mathbf{2 . 9 5}$ \\
\hline Me & 3.50 & 3.75 & 3.25 & 3.20 \\
\hline SD & 0.62 & 0.72 & 0.66 & 0.89 \\
\hline Min. & 1.75 & 1.00 & 1.75 & 1.00 \\
\hline Max. & 4.00 & 4.00 & 4.00 & 4.00 \\
\hline
\end{tabular}

Source: Compiled by authors.

1) Perceived available instrumental support was rated the highest by the respondents suffering from a chronic illness, with the result $\mathrm{M}=3.46$ close to the maximum value $(\operatorname{Min}=1.75, \operatorname{Max}=4.00)$. Thus, it can be concluded that the respondents in a difficult illness condition were most likely to need instrumental support, which mainly involved receiving specific information about how to cope with their condition and what to do.

Instrumental support was followed by 2) emotional support, with the result above the mean value $\mathrm{M}=3.37$ ( $\mathrm{Min}=1.00, \mathrm{Max}=4.00$ ). Thus, it can be stated that emotional support is almost as important as instrumental support when experiencing the situation of an illness; it most often refers to the need for being cared about, feeling a sense of security and closeness.

In the study group, 3$)$ the need for support $\mathrm{M}=2.98,(\mathrm{Min}=1.75, \mathrm{Max}=4.00)$ and 4) support seeking $\mathrm{M}=2.95$, ( $\mathrm{Min}=1.00$, Max $=4.00)$ were ranked at a level slightly above the mean value, which means that the respondents suffering from a chronic illness expressed the general need for support and support seeking at an average level.

The obtained mean results between different types of perceived and sought support did not show statistically significant differences. Therefore, the above analysis is more of a qualitative nature.

Fig. 4 below gives a graphic illustration of emotions accompanying illness.

When treated with haemodialysis, the patients under study were most likely to feel fatigue and exhaustion $(\mathrm{N}=17$, i.e. $42.5 \%)$, anxiety $(\mathrm{N}=10$, i.e. $25.0 \%)$, sadness and loneliness $(\mathrm{N}=2$, i.e. $5 \%)$, and stress and depression $(\mathrm{N}=2$, i.e. $5 \%)$. Nine respondents $(\mathrm{N}=9$, i.e. $22.5 \%)$ reported no changes in mood resulting from their illness and treatment.

The experience of an illness and the need to undergo haemodialysis treatment placed some limitations on how the respondents functioned in the family and society. Table 2 below presents data on various aspects of life that have been limited to a different extent, due to a chronic illness and its treatment. 
$42.5 \%$ - fatigue and exhaustion, $25.0 \%$ - anxiety, $22.5 \%$ - no change in mood, $5.0 \%$ - sadness and loneliness, $5.0 \%$ - stress, depression.

Fig. 4. Emotional states accompanying illness in the studied group

Source: Compiled by authors.

Table 2. Selected aspects of life that have been limited since the beginning of haemodialysis treatment in the study group

\begin{tabular}{|l|c|c|c|c|c|c|c|c|}
\hline \multirow{2}{*}{ Variables: } & \multicolumn{2}{|c|}{ Completely } & \multicolumn{2}{c|}{$\begin{array}{c}\text { To some } \\
\text { extent }\end{array}$} & \multicolumn{2}{c|}{ Not at all } & \multicolumn{2}{c|}{$\begin{array}{c}\text { Non } \\
\text { applicable }\end{array}$} \\
\cline { 2 - 9 } & $\mathrm{N}$ & $\%$ & $\mathrm{~N}$ & $\%$ & $\mathrm{~N}$ & $\%$ & $\mathrm{~N}$ & $\%$ \\
\hline Work life & $\mathbf{1 1}$ & $\mathbf{2 7 . 5 \%}$ & $\mathbf{1 2}$ & $\mathbf{3 0 . 0 \%}$ & 3 & $7.5 \%$ & $\mathbf{1 4}$ & $\mathbf{3 5 . 0 \%}$ \\
\hline Social life & 5 & $12.5 \%$ & $\mathbf{1 8}$ & $\mathbf{4 5 . 0 \%}$ & 8 & $20.0 \%$ & 9 & $22.5 \%$ \\
\hline $\begin{array}{l}\text { Education and } \\
\text { development }\end{array}$ & 5 & $12.5 \%$ & 3 & $7.5 \%$ & 9 & $22.5 \%$ & $\mathbf{2 3}$ & $\mathbf{5 7 . 5 \%}$ \\
\hline Entertainment & 5 & $12.5 \%$ & $\mathbf{1 9}$ & $\mathbf{4 7 . 5 \%}$ & 2 & $5.0 \%$ & $\mathbf{1 4}$ & $\mathbf{3 5 . 0 \%}$ \\
\hline Leisure travel & $\mathbf{1 3}$ & $\mathbf{3 2 . 5 \%}$ & $\mathbf{1 3}$ & $\mathbf{3 2 . 5 \%}$ & 2 & $5.0 \%$ & $\mathbf{1 2}$ & $\mathbf{3 0 . 0 \%}$ \\
\hline Interests and hobbies & 3 & $7.5 \%$ & $\mathbf{1 4}$ & $\mathbf{3 5 . 0 \%}$ & 7 & $17.5 \%$ & $\mathbf{1 6}$ & $\mathbf{4 0 . 0 \%}$ \\
\hline Pursuing goals & 4 & $10.0 \%$ & $\mathbf{1 5}$ & $\mathbf{3 7 . 5 \%}$ & 3 & $7.5 \%$ & $\mathbf{1 8}$ & $\mathbf{4 5 . 0 \%}$ \\
\hline
\end{tabular}

Source: Compiled by authors.

Based on the obtained results given in Table 2, it can be concluded that various life areas and activities of patients were limited completely or to some extent, as a result of their chronic illness or more precisely, as a result of haemodialysis treatment.

In the group under study, $32.5 \%$ respondents $(\mathrm{N}=13)$ stated that haemodialysis treatments put an end to leisure travel and $27.5 \%(\mathrm{~N}=11)$ claimed that these completely limited their work activity. Few respondents reported limitations in their social life, education and personal development, entertainment $(\mathrm{N}=5$, i.e. $12.5 \%)$, pursuing some goal in life $(\mathrm{N}=4,10.0 \%)$, as well as pursuing their interests and hobbies $(\mathrm{N}=3$, i.e. $7.5 \%)$. 
In the study group, haemodialysis treatments partly limited entertainment opportunities $(\mathrm{N}=19,47.5 \%)$, social life $(\mathrm{N}=18,45.0 \%)$, pursuing the goals $(\mathrm{N}=15,37.5 \%)$, pursuing interests $(\mathrm{N}=14,35.0 \%)$, leisure travel $(\mathrm{N}=13,32.5 \%)$, professional life $(\mathrm{N}=12,30.0 \%)$. Only a few patients felt that their education and development opportunities were limited $(\mathrm{N}=3,7.5 \%)$.

When examining the areas of life affected by an illness and its treatment, it is worth drawing attention to the data concerning those areas that the respondents believe were in no way limited as a result of their illness and treatment. 23 respondents $(\mathrm{N}=23 ; 57.7 \%)$ did not feel any limitations when it came to their education and development. 18 respondents (i.e. $45 \%$ ) did not feel restricted in pursuing their goals, $16(40.0 \%)$ - in pursuing their interests, 14 respondents $(30.0 \%)$ reported no limitations to their professional life and entertainment, 12 respondents $(30.0 \%)$ stated that leisure travel had not been affected, while 9 respondents $(22.5 \%)$ believed that their social life had not been limited.

\section{DISCUSSION}

There are some difficult moments and situations in human life, e.g. a chronic illness, when the individual needs the support from another person or from an institution. The chronic illness, long-term treatment and the resulting limitations in various areas of life often make it impossible for patients to stay fully independent and resourceful. Support in such life situations mainly concerns interactions and is tantamount to providing help and consequently, it involves: working, taking effort and action for the benefit of another person in order to ease the difficulties they experience (Kacperczak, 2006).

One of the major stressful situations in human life is illness. Thus, providing support in such situations is of key importance. Lack of adequate support can lead to depression, discouragement and withdrawal.

Based on the results obtained in the group under study, the following conclusions can be formulated:

1. Emotional support is the most expected type of support by those facing a difficult situation, such as a chronic disease. A large percentage of respondents put first the need for emotional support in a difficult life situation. In the group under study, family and social ties are considered to be more important than other types of support; e.g., instrumental, material or spiritual. According to Kurowska \& Weselska (2015), maintaining good relationships and close emotional ties with other people enables us to build up our personal resources for coping with a difficult situation and activates additional energy and resourcefulness.

2. Perceived available instrumental and emotional support are rated the highest by the respondents suffering from a chronic illness. Based on the obtained results, it can be concluded that the respondents in a difficult illness condition were most likely to need instrumental support, which mainly involved receiving specific information about how to cope with their condition. The research conducted by Grochowska, Kurzawska, Bodys-Cupak (2016) also shows that both the patient's family and friends, as well as specialists constitute the so-called basic supporting network. Lack of support from the family and specialists strengthens the patients' feelings of helplessness, confusion and not being able to cope.

3. The difficult illness condition and haemodialysis treatment are accompanied by emotional states such as: fatigue, exhaustion, and anxiety. Studies have shown that 
although patients may have partially or completely accepted their illness and taken a conscious decision to start dialysis therapy, many of them feel tired, exhausted, anxious, sad and resentful because they are forced to change their lifestyle and face new limitations due to increasing side effects of haemodialysis. Bereza (2009) states that haemodialysis is a burdensome treatment that is necessary for the rest of a patient's life, and the numerous limitations that go with it constitute a heavy mental strain for patients.

4. A difficult situation such as a chronic illness, places some limitations on how the respondents can function in their lives. Based on the research findings, it can be concluded that a chronic illness and its treatment limit the social activity of patients in some ways. Chronic dialysis patients are not likely to participate in social or cultural life and in leisure pursuits. Illness and its treatment have become the priority in their lives.

\section{CONCLUSION}

Based on the research findings, it can be concluded that the respondents experiencing a difficult life situation such as a chronic illness:

- were most likely to expect and need emotional and informational support;

- rated the perceived available instrumental support highest, followed by the perceived emotional support.

When undergoing treatment related to their illness, they were most likely to feel fatigue and exhaustion, anxiety, sadness and loneliness, as well as stress and depressed mood.

In the group of patients under study, treatment related to the disease:

- put an end to their leisure travel and often also to their work life;

- limited their social life and the ability to pursue goals and interests, for a few respondents;

- Some respondents believe that their treatment did not restrict their education opportunities and development, among others.

\section{REFERENCES}

Baum, E. (2017). Jakość życia chorych poddawanych terapii nerkozastępczej. Poznań: Wydawnictwo Naukowe Uniwersytetu Medycznego im. K. Marcinkowskiego w Poznaniu.

Bereza, B. (2009). Doświadczanie własnej choroby przez pacjentów dializowanych. Lublin: Towarzystwo Naukowe KUL.

Filipiak, G. (2010). Funkcja wsparcia społecznego w rodzinie. Poznań: Wydawnictwo UAM.

Grochowska, A., Kurzawska, M., Bodys-Cupak, I. (2016). Wsparcie a jakość życia pacjentów dializowanych w Tarnowie. „, Polski Przeglad Nauk o Zdrowiu”, No. 2 (47).

Kacperczyk, A. (2006). Wsparcie społeczne w instytucjach opieki paliatywnej i hospicyjnej. W: Kaptacz, A. De Walden-Gałuszko, K. ed., Pielęgniarstwo opieki paliatywnej. Warszawa: Wydawnictwo Lekarskie PZWL.

Kurowska, K., Weselska, M. (2015). Rola wsparcie a przystosowanie się do życia osób dializowanych. „Nefrologia i Dializoterapia Polska”, No. 19.

Lichodziejewska-Niemierko, M. (2016). Jakość życia u chorych na nerki. „Dializa i Ty”, No. 1(27). 
Marcinkowska, U., Zabiegaj, U., Kulik, H. (2018). Interakcje społeczne $i$ wsparcie spoteczne u chorych leczonych nerkozastepczo metoda hemodializy. „Nefrologia i Dializoterapia Polska”, No. 22.

Sęk, H., Cieślak, B. (ed.) (2004). Wsparcie społeczne, stres i zdrowie. Warszawa: Państwowe Wydawnictwo Naukowe.

Wiśniewska, L., Paczkowska, B., Białobrzeska, B. (2010). Zapotrzebowanie na wsparcie emocjonalne wśród pacjentów leczonych nerkozastępczo. „Forum Nefrologiczne”, No. 3(1).

Ziarko, M. (2014). Zmaganie się ze stresem choroby przewlektej. Poznań: UAM Poznań.

DOI: $10.7862 /$ rz.2020.hss.49

The text was submitted to the editorial office: November 2020.

The text was accepted for publication: December 2020. 